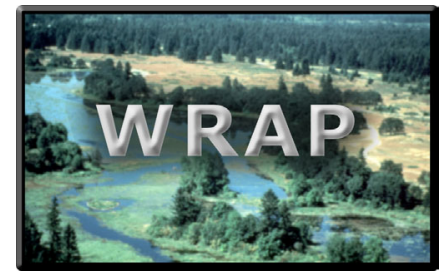

\title{
Duration and Frequency of Ponded Water on Arid Southwestern Playas
}

by Robert Lichvar, Greg Gustina, Robert Bolus

PURPOSE: Playas, "[t]he flat-floored bottom of an undrained desert basin that becomes at times a shallow lake which on evaporation may leave a deposit of salt or gypsum," are regulated by the U.S. Army Corps of Engineers (Corps) under the provisions of the Code of Federal Regulations 33 CFR 328.3 [a] implementing Section 404 of the Clean Water Act (CWA). The Corps and others perform jurisdictional delineations of playas to determine whether certain areas are subject to Section 404 regulations. However, delineating playas has been found to be problematic (e.g., Doug and Colberg 1996; Lichvar and Sprecher 1996; Brostoff, Lichvar, and Sprecher 2001). Case studies have been performed for several playas in the western Mojave Desert, California, to examine surface hydrology. The purpose of this study was to estimate the duration and frequency of inundation at these playas.

INTRODUCTION: Many federal, state, and private sector personnel involved in the delineation of playas are inclined to apply wetland delineation protocols to playas. However, there are differences in both the rules and characteristics available for differentiating wetlands and playas. In the case of wetlands, there are formal definitions and guidelines. Wetlands are identified on the basis of three parameters: soils, vegetation, and hydrology, as specified in the Corps of Engineers Wetlands Delineation Manual (Environmental Laboratory 1987). Wetland hydrology must, by definition ("frequency and duration criteria"; Office of the Chief of Engineers 1992) be met for 1-2 weeks of the year (or 5 percent of the growing season). Playas are, by definition, intermittently covered with water, the extent of cover changing rapidly on both short- and long-term time scales (e.g., Kubly (1982)), making it hard to assess "frequency and duration" criteria for hydrology.

For playas, the guidance is included in the definition of "Waters of the United States" (WoUS):

The term 'waters of the United States' means (1) all waters which are currently used, or were used in the past, or may be susceptible to use in interstate or foreign commerce, including all waters which are subject to the ebb and flow of the tide; (2) all interstate waters including interstate wetlands; (3) all other waters such as intrastate lakes, rivers, streams (including wet intermittent streams), mudflats, sandflats, wetlands, sloughs, prairie potholes, meadows, playa lakes or natural ponds, the use, degradation or destruction of which could affect interstate or foreign commerce...; (4) all impoundments of waters otherwise defined as waters of the United States under the definition; (5) tributaries of waters identified in [items] (1)(4) [of this definition]; (6) the territorial seas; (7) wetlands adjacent to waters (other than waters that are themselves wetlands) identified in [items] (1)-(6) [of this definition] (33 CFR 328.3[a]).

\footnotetext{
${ }^{1}$ Webster's Third New International Dictionary. Springfield, MA: Merriam Webster.
} 
All of these waters, except wetlands (which may co-occur with non-wetland WoUS), are delineated to the extent of Ordinary High Water (OHW) or high tide levels. OHW is defined as

...that line on the shore established by fluctuations of water and indicated by physical characteristics such as clear, natural, lines impressed on the bank, shelving, changes in the character of the soil, destruction of terrestrial vegetation, the presence of litter and debris, or other appropriate means that consider the characteristics of the surrounding area. (33 CFR 328.3[e])

The criteria for frequency and duration for OHW have not been defined under the CWA or any guidance from the Corps for field delineators. In an effort to provide background information concerning physical characteristics of xeric fluvial systems, Corps Districts in the southwestern United States have provided guidelines for making jurisdictional determinations for WoUS, including playas, but have not provided any guidance for the requirements of frequency or duration of ponding or flowing waters (U.S. Army Engineer Division, South Pacific 2001). In addition, few technical data are available documenting the areal extent of inundation of playas or other aspects of playa hydrology (Rosen 1994).

In an effort to provide support evidence about the frequency and duration of surface hydrology of playas in the arid Southwest, case studies were performed for several playas in the western Mojave Desert, California. The purpose of this study was to estimate the frequency of playa inundation lasting 16 days (typical Landsat frequency) or more by coupling available Landsat images from the past 21 years with precipitation data from the last 50 years.

\section{METHODS}

Study Area. Areas on three playas on Edwards Air Force Base (Edwards AFB), Kern County, California were evaluated. Edwards AFB is in the far western Mojave Desert northeast of Los Angeles. The study area included the eastern half of Rosamond, all of Buckhorn, and a small southwestern portion of Rogers dry lake (Figure 1).

The playas are contained within the boundary of the Pleistocene Lake Thompson bed (Orme 2000). Pleistocene Lake Thompson filled most of Antelope Valley to elevations of approximately 2275 to $2350 \mathrm{ft}$ (ca $710 \mathrm{~m})$. Following Holocene desiccation and widespread progradation of alluvial and aeolian deposits, Lake Thompson is presently reflected in two significant dry lakes, Rosamond in the west and Rogers in the east, separated by a suite of smaller lakes of which Buckhorn is the largest (Orme 2000). Rosamond dry lake presently covers approximately $53 \mathrm{~km}^{2}$ and its bare playa surface is roughly circular in shape with a diameter of about $9 \mathrm{~km}$. Rogers dry lake, covering about $114 \mathrm{~km}^{2}$, is somewhat rectangular in shape with its longer north-south axis measuring $20 \mathrm{~km}$ and its shorter east-west axis about $10 \mathrm{~km}$. Buckhorn dry lake covers about $5 \mathrm{~km}^{2}$ and its longer east-west axis is approximately $4 \mathrm{~km}$. The center of Lake Thompson lay near the southeast margin of Rosamond dry lake and its now emergent lake floor is widely present to the south and west of Rosamond dry lake, where it eventually passes beneath recent fluvial deposits derived from the nearby mountains. The majority of the vegetation located on the Pleistocene lakebed is composed of members of the chenopod family with several phases of saltbush plant communities, although the playa surfaces are devoid of vegetation. 


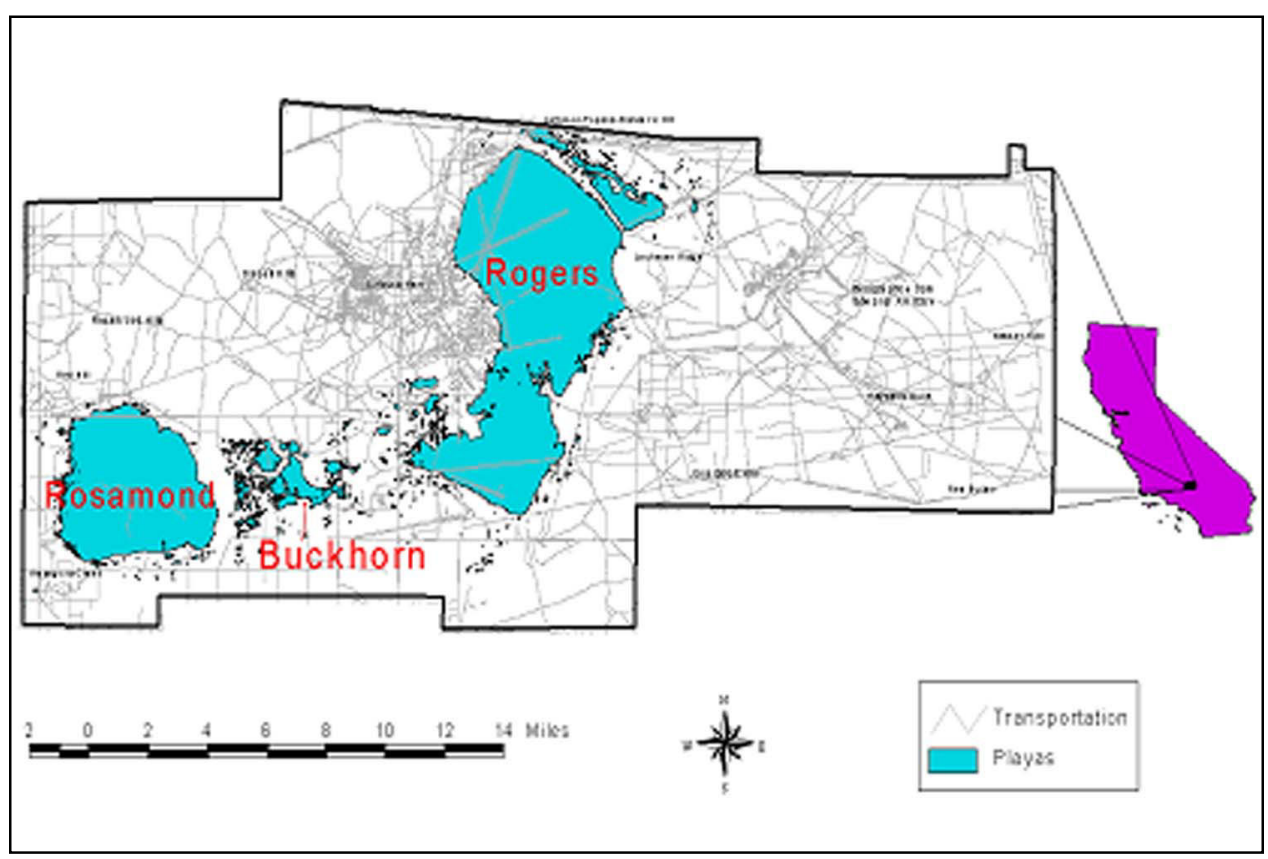

Figure 1. Location of study playas on Edwards Air Force Base, CA

Under present climatic conditions wherein annual precipitation averages $13 \mathrm{~cm}$ and annual evapotranspiration averages $280 \mathrm{~cm}$, the surface of the remnant lakes remains dry for most of the year, sometimes for several years (Orme 2000). However, winter rainstorms related to eastwardmoving cyclonic systems from the Pacific Ocean, and summer thunderstorms related to moist monsoonal flows moving northward from the Gulf of California and the neighboring tropical Pacific, may sometimes inundate these dry lake beds, the duration of flooding depending on the magnitude and location of precipitation and ambient climatic conditions over the lakes. Significant temporary flooding may be associated with El Niño climatic conditions when warmer than average surface waters of the eastern Pacific Ocean near the California coast favor the onshore movement of very moist air masses that lead to locally heavy precipitation. This pattern was documented for the region during the 1982-83 water year. These temporary floods in turn introduce modest amounts of fresh fluvial sediment to the system, notably to Rosamond, while shallow-water waves locally rework shoreline deposits into swash bars a few centimeters high. These features are, however, negligible in comparison with the larger bars and barriers formed under higher lake stands and wave action of the wetter past.

Satellite Data. The effort to establish the frequency and duration of ponded waters on playas in the Mojave Desert required both current and archival satellite imagery relevant to the study. Current imagery was acquired from February through May of 2001 from the Multi-spectral Thermal Imager (MTI) sensor on board a Department of Energy satellite. Two successive daily images were taken at intervals of approximately 16 days over that time period. Since the sensor bands were electrooptical and thermal, clouds were able to block imaging of the ground. But by imaging on successive days, the probability of blockage was lowered to the point where a complete record of seven clear shots at roughly 16-day intervals was acquired in the early part of the year. 
Landsat 4, 5, and 7 Thematic Mapper (TM) imagery was purchased from the USGS archive at the EROS Data Center in Sioux Falls, SD. The interval of the Landsat is every 16 days, with only one image per interval taken regardless of cloud cover. Available data were acquired from the beginning of the TM archive starting in 1982 up to and including January 2001. Table 1 is a list of image scenes acquired for processing. Additionally, 12 to 14 archived quick-look images with reduced resolution were obtained from the USGS Web page for the January through July time frame for each of the years 1985, 1987, 1992, and 2000. These were used to verify that ponding occurred for a minimum of two sequences (16 days) and to determine the total length of time that water remained ponded in the study area in the years analyzed.

The MTI sensor closely duplicates the red-green-blue (RGB) reflective bands of the Landsats, splits the near infrared (NIR) of the Landsats into two bands, adds two more NIR and an atmospheric water absorption band, and closely duplicates the mid-infrared bands of the Landsats. Because it is specified as a multi-spectral thermal imager, it has five thermal bands, one of which is close to the Landsat thermal band. The MTI sensor has a 5-m ground sample distance (GSD) in its RGB and NIR bands, and a 20-m GSD for all other bands. Its radiometric accuracy is specified at 3 percent in the reflective region and 1 percent in the thermal region of the spectrum. In contrast, the Landsat 4 and $5 \mathrm{TM}$ has a 30-m GSD in its reflective bands and a 120-m GSD thermal band. Landsat 7 is similar to its predecessors, but has an extra $15-\mathrm{m}$ pan band and a $60-\mathrm{m}$ thermal band. Its radiometric accuracy is specified at 5 percent.

\begin{tabular}{|c|c|}
\hline $\begin{array}{l}\text { Table } 1 \\
\text { Satellite Images Obtained for Processing }\end{array}$ & Type and Date \\
\hline Landsat 4 TM & Landsat $7 \mathrm{TM}$ \\
\hline $12 / 10 / 82 \quad 12 / 26 / 82$ & $\begin{array}{l}3 / 14 / 00 \\
1 / 28 / 01\end{array}$ \\
\hline Landsat 5 TM & DOE MTI \\
\hline 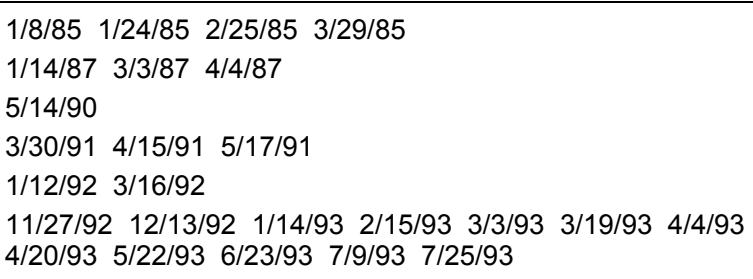 & 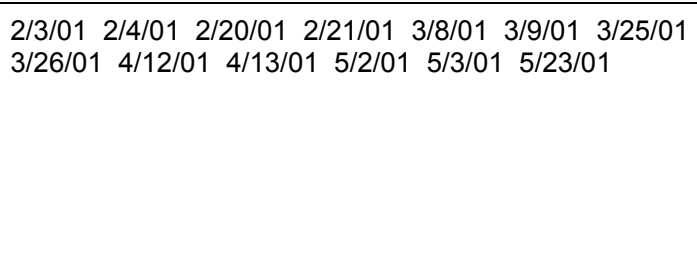 \\
\hline
\end{tabular}

All MTI and Landsat image scenes were mapped into color composites using the red, green, and blue visible bands. These maps show the area as non-colorful, rather gray-looking imagery, but with definite differences in the color of the pooled water depending on when and where it occurred. The projection was into an Alber's Conical Equal Area coordinate system for minimum distortion of ground area. They are co-registered such that the same pixel shows up at the same location on the ground in each image file. When looking at these image maps only, it is not possible to accurately assess where water has pooled.

Therefore, each image scene was classified by the ratio of band 5 to band 2 . This gave a gray level image made up of floating point numbers ranging from 0 to 4 or 5 . The ratio threshold using the known pooled areas shown on the MTI for RGB scenes was set at a level of 1 to separate pooled 
from non-pooled water in the imagery. Every value above was driven into saturation or display white and every value below was driven to zero or display black. Co-registered pooled water maps were made in this way with the same projection as the imagery maps. A close correlation was observed between the classified products and field-verified pooled areas on the ground for the early 2001 imagery.

Climate Data. Climate data used for precipitation analyses were provided by the $412^{\text {th }}$ Operations Support Squadron, Weather Flight Office (OSS/OSW) on Edwards Air Force Base. ${ }^{1}$ Data containing daily total precipitation in inches were collected from January 1942 to present at the main base area. For years that had available Landsat imagery, precipitation was summed from October $1^{\text {st }}$ to the date at which ponding was first visible and remained for at least two consecutive images. Validating ponding for two consecutive images assured a duration of greater than 16 days, since Landsats are taken every 16 days. This is a conservative approach because ponding visible for only one image could correspond to a duration of up to 31 days: 15 days before, 15 days after, and day of image capture. Precipitation summaries for years analyzed were averaged together to develop a threshold rainfall bracket of average minimum precipitation needed $+/$ - the error. Frequency of ponding was determined by reviewing the historical climate record since 1942 to find the number of years that equaled or exceeded threshold precipitation between October 1 and March 31.

\section{RESULTS}

Processing Satellite Image Data. When the reflectance spectrum of water is examined, the maximum reflectance occurs at the green wavelengths, all other appreciable reflectance occurs in the visible bands, and almost no reflectance occurs in the infrared bands. The soil spectrum shows values throughout the reflective region with its own characteristic shape as does the vegetation spectrum. The interesting fact about these spectra is that the ratio of band 5 to band 2 is always greater than 1 for the non-water objects and always less than 1 for the water bodies. This is an opportunistic result, since the imagery forms a time series over several years and seasons where the sun's illumination is changing, the atmosphere is changing, and the sediments in the pooled water are changing. In other words, it would be very difficult to work with any classifier that was not formed by some sort of ratio of reflected energy to input energy. Even though transmissions through the atmospheric and water media are not quite the same at band 2 as at band 5, they are close enough to virtually consider this ratio as an invariant indicator over time.

Satellite Images. Direct analysis of ponding via satellite images was limited to eight years total, including seven for frequency and six for duration. An example of a processed image is shown in Figure 2. This limit was due to an incomplete image archival record and cloudy conditions. Image data from May 14, 1990 were obtained to verify no ponding in years when precipitation does not reach the threshold prior to the end of March. Threshold precipitation for 1987 could not be estimated because two consecutive images were not verified with ponding.

\footnotetext{
${ }^{1}$ Personal Communication. 2001. Phil Harvey, $412^{\text {th }}$ Operations Support Squadron, Weather Flight Office, Edwards Air Force Base, CA.
} 


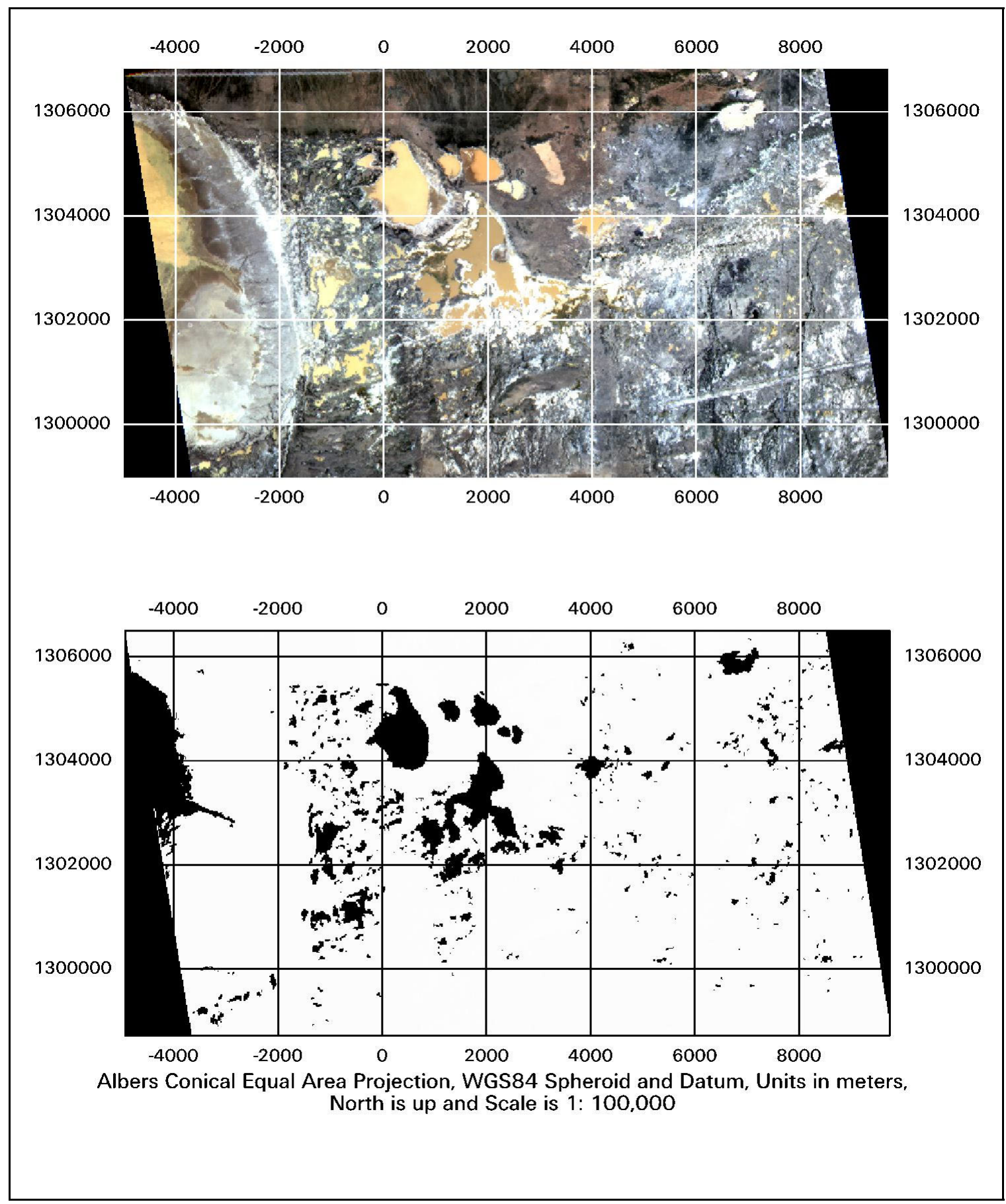

Figure 2. Example of true color MTI satellite image (top) showing the study area with water ponded on Rosamond and Buckhorn and image processing result for the same area (bottom) showing ponded surfaces in black

Climate Data. Precipitation records from seven winter seasons, matching available satellite imagery, were used to calculate the threshold average precipitation. These included: 1982-83, 198485, 1990-91, 1991-92, 1992-93, 1999-2000, and 2000-01. Precipitation totals for the period from October 1 to the first visible ponding on satellite images range from 2.14 in. to 5.25 in. (Table 2). 
Average threshold precipitation for these years was 3.26 in. with a standard deviation of 1.33. Maximum and minimum threshold precipitation was calculated as the average \pm 1 standard deviation, respectively.

\begin{tabular}{|c|c|}
\hline \multicolumn{2}{|c|}{$\begin{array}{l}\text { Table } 2 \\
\text { Threshold Precipitation Data and Bracketing Dates for } \\
\text { Known Ponded Years in Which Ponding was Verified by } \\
\text { Satellite }\end{array}$} \\
\hline Threshold Precipitation & Dates \\
\hline 2.39 & 10/01/82-12/10/82 \\
\hline 4.79 & 10/01/84-01/08/85 \\
\hline 5.25 & 10/01/90-03/30/91 \\
\hline 2.27 & 10/01/91-01/12/92 \\
\hline 3.75 & 10/01/92-12/13/92 \\
\hline 2.26 & 10/01/99-03/14/00 \\
\hline 2.14 & 10/01/00-01/11/01 \\
\hline 3.26 & Average \\
\hline 1.33 & Standard Deviation \\
\hline 4.59 & Avg + s.d. (Max) \\
\hline 1.93 & Avg - s.d. (Min) \\
\hline
\end{tabular}

Frequency and Duration. Frequency of inundation was calculated as the number of years exceeding the threshold level divided by total number of years analyzed. It is estimated that from 1942 to 2001, playas in the study area ponded with a frequency of 0.51 (or every other year based on an average precipitation threshold of 3.26). The frequencies based on maximum and minimum thresholds are 0.39 (about 1 of 3 years) and 0.78 ( 3 of 4 years), respectively. Precipitation analyses also show that inundation was probably less frequent from 1951 to 1981 than over the past 20 years. Figure 3 shows winter precipitation totals for each year ordered chronologically.

Duration of ponding on playa surfaces in the study area was analyzed in three ways. First, it was verified that all analyzed images represented one of two consecutive images showing ponding. Thus, for all years analyzed, the study area had at least some ponding for a minimum of 16 days.

Once this minimum ponding duration was verified, available images were analyzed for the period after March 3 to determine if ponding was present for at least 14 days during the growing season. The growing season was defined as March 3 to November 21 (U.S. Department of Agriculture 1997). No images were available for 1983 (winter 1982-83), so available images for March 1987 (winter 1986-87) were used to maintain seven years of record. Analysis of images starting on March 3 verified that for the years analyzed, some part of the playa surface was inundated for at least 14 days during the growing season. 


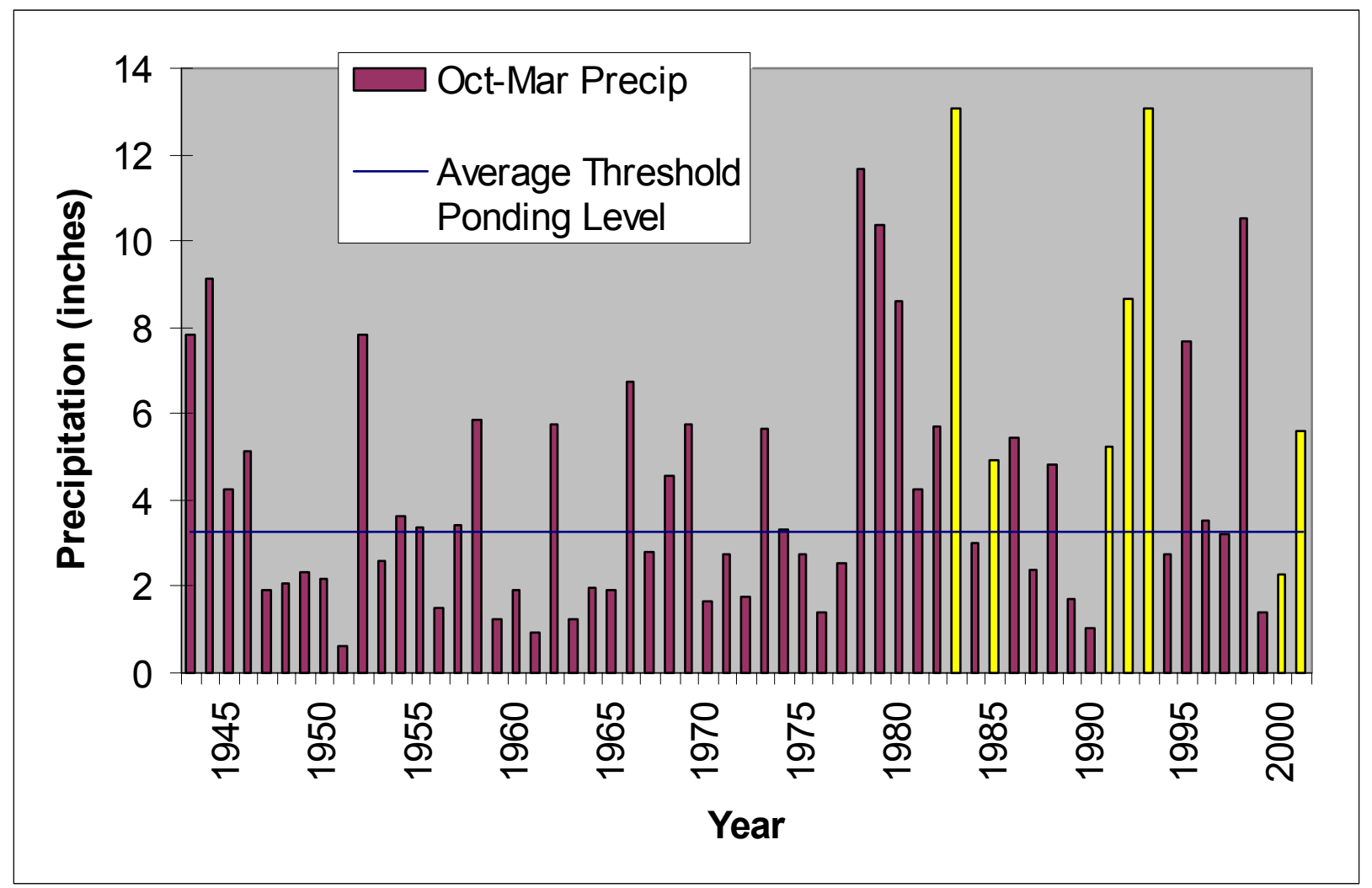

Figure 3. Winter precipitation (Oct 1 to Mar 31) since 1942 by year in chronological order (years analyzed shown with light bars)

The last analysis for duration involved the determination of total length of time in weeks that at least some water remained on playa surfaces. For this study, full images were supplemented with the archived snapshot images, which lack fine resolution. When these images were used, only conservative estimates of duration were made. Generally, the length of duration was linearly related to the amount of precipitation received during the winter (Table 3, Figure 4). However, there was one outlier, 1986-87, which significantly altered the relationship. This may be due to the fact that temporal resolution is 2 weeks at best.

DISCUSSION: The authors found no previous literature that has attempted to establish duration and frequency of ponding on playas in the arid Southwest. The analyses in this technical note describe the duration and frequency of a WoUS playa system that would also meet the hydrology criteria established for wetlands (Environmental Laboratory 1987, Office of the Chief of Engineers 1992). We found that ponding occurs at least every other year based on winter precipitation of 3.27 in. and that in years exceeding this threshold, ponding will be present for at least 14 days during the growing season. The analysis of duration also produced a linear relationship between amount of rain and total weeks that the playa remained ponded with a range of 1 to 32 weeks duration for the six years analyzed. 


\begin{tabular}{|c|c|c|}
\hline \multicolumn{3}{|c|}{$\begin{array}{l}\text { Table } 3 \\
\text { Winter Precipitation by Years and Weeks of } \\
\text { Inundation }\end{array}$} \\
\hline Precipitation Oct -Mar & Years & Weeks Inundated \\
\hline 2.37 & $1986-87^{1}$ & 1 \\
\hline 2.26 & 1999-00 & 6 \\
\hline 4.94 & $1984-85^{1}$ & 14 \\
\hline 5.6 & 2000-01 & 16 \\
\hline 8.66 & $1991-92^{1}$ & 25 \\
\hline 13.05 & 1992-93 & 32 \\
\hline
\end{tabular}

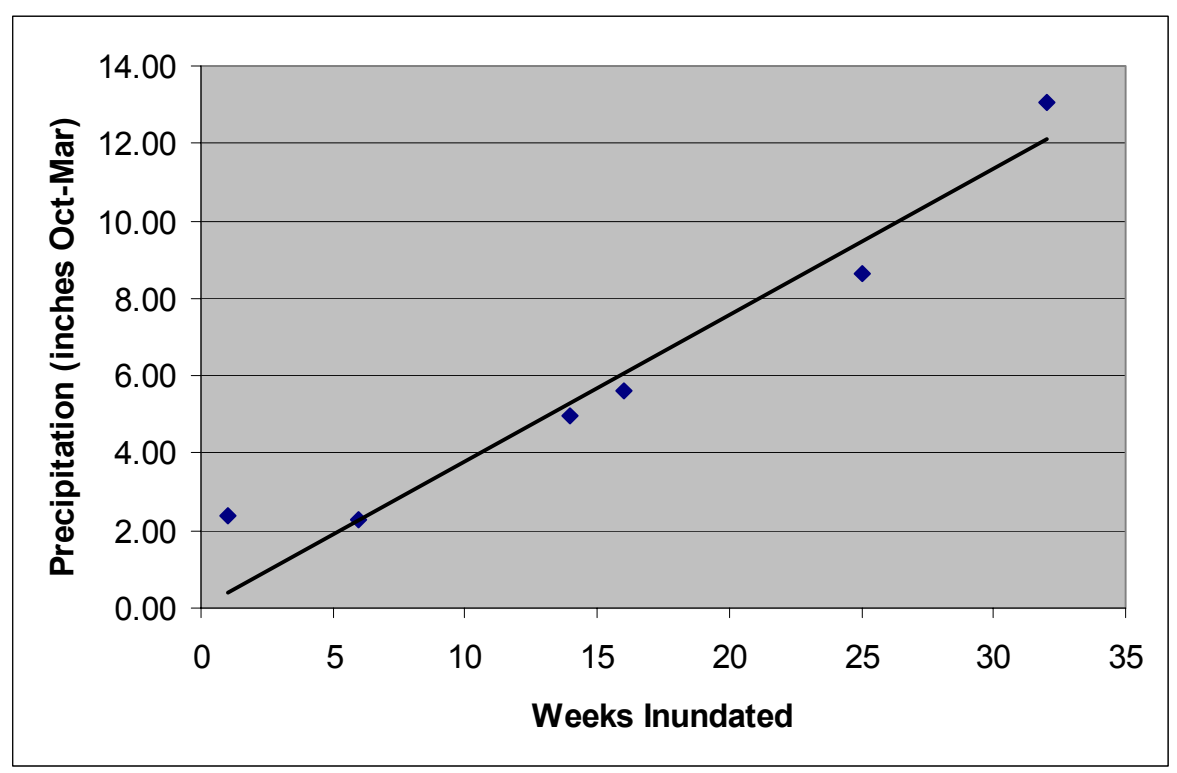

Figure 4. Plot of duration by winter precipitation amount for six years with linear trendline forced through zero

Study results also show that despite general warming trends around the world in the past decade, these playas have actually experienced an increased frequency of inundation relative to the third quarter of the $20^{\text {th }}$ century as a result of increased precipitation amounts during the winter. This result is not entirely surprising, since rainfall in this region of the Mojave is influenced by El Niño events that are driven by increased ocean temperatures off the coast of California. Of the top five precipitation years over the past 20 years, all are confirmed to have occurred during El Niño events (Redmond 2001), including the two largest precipitation years on record at Edwards AFB. 
The model presented herein is a fairly simple design that views the playas as a sink that will fill up once a given amount of water is received in the watershed. Although this simple model may be able to handle playa dynamics on a small spatial scale, the authors believe a more accurate model could be created for larger regions with the addition of particular environmental parameters. For example, evapotranspiration plays a large role in determining water losses from desert watersheds. Combining precipitation and evapotranspiration data could provide a robust model of playa inundation for the entire desert region.

Soils are also a major factor to consider, as they control playa ponding characteristics. Impermeable soils at shallow depths are likely to result in ponding at lower precipitation levels. Significant differences in ponding among hard playa surfaces in this small study area can be related to differences in soil features (Brostoff, Lichvar, and Sprecher 2001). Further work connecting soil characteristics to ponding frequency and threshold precipitation is necessary to extend the model to other desert playas.

Another aspect of ponding that needs to be analyzed is storm event impact. The analysis presented here does not clearly show whether long-term winter rain patterns have the same effect as higher intensity, short-term storm events on playa inundation. Event analysis also is important in determining seasonal variations of ponding. It was assumed that winter weather would have more impact on ponding frequency than weather in drier seasons. Although summer storm events are highly localized, they may contribute significantly to playa hydrology.

Despite some of the difficulties in obtaining satellite imagery, research indicates that fundamental regulatory issues can be addressed using advanced technology. More research on playa hydrology and hydrology of other unique waters may provide opportunities in determining appropriate delineation boundaries.

\section{ACKNOWLEDGEMENTS}

The authors gratefully acknowledge The Department of Energy Multi-spectral Thermal Imager mission at Los Alamos and Sandia National Laboratories for providing imagery that was processed into level 1 co-registered and reflectance at top of atmosphere data. The authors also acknowledge Edwards Air Force Base for allowing satellite overflights.

\section{REFERENCES}

Brostoff, W., Lichvar, R., and Sprecher, S. (2001). "Delineating playas in the arid Southwest: A literature review," Technical Report ERDC TR-01-4, U.S. Army Engineer Research and Development Center, Hanover, NH.

Doug, P. J., and Colberg, J. (1996). “Delineation of playa features in the western Great Basin,” Wetland Journal 8, 6-13.

Environmental Laboratory. (1987). "Wetlands delineation manual," Technical Report Y-87-1, U.S. Army Engineer Waterways Experiment Station, Vicksburg, MS.

Kubly, D.M. (1982). "Physical and chemical features of playa lakes in southeastern California, U.S.A.," Archives of Hydrobiology Supplement 62, 491-525. 
Lichvar, R., and Sprecher, S. (1996). "Delineation and characterization of 'Waters of the United States' at Edwards Air Force Base, California," unpublished report, U.S. Army Engineer Waterways Experiment Station, Vicksburg, MS.

Office of the Chief of Engineers. (1992). "Clarification and Interpretation of the 1987 Manual," Washington, DC.

Orme, A. (2000). "Geomorphic classification report," Appendix B in Lichvar, R., Sprecher, S., Orme, A., Gustina, G., MacDonald, D., Ericsson, M., Racine, C., Campbell, J., and Kane, A. (2000). Ecological land classification and floodplain assessment for Pleistocene Lake Thompson bed; a comprehensive report including Phase I: Rosamond Dry Lake and Phase II: Buckhorn and Rogers Dry Lakes, draft report submitted to Edwards AFB by Cold Regions Research and Engineering Laboratory, Hanover, NH.

Redmond, K. (2001). "Northern Hemisphere Oct-Mar El Niño vs La Niña. 700 Mb Height Anomalies," Western Regional Climate Center. http://www.wrcc.dri.edu/enso/700enln.html

Rosen, M. R. (1994). "The importance of groundwater in playas: A review of playa classifications and the sedimentology and hydrology of playas," Paleoclimate and basin evolution of playa systems: Boulder, Colorado. M.R. Rosen, ed., Geological Society of America Special Paper 289.

U.S. Army Engineer Division, South Pacific (2001). "Final Summary Report: Guidelines for jurisdictional determinations for 'Waters of the United States' in the arid Southwest." http://www.spl.usace.army.mil/co/co5.html\#reg.

U.S. Department of Agriculture. (1997). "Climatic analysis for wetlands by county," http://www.wcc.nrcs.usda.gov/ water/wetlands.html. Accessed September 2001.

POINT OF CONTACT: For additional information, contact the program manager of the Wetlands Regulatory Assistance Program, Mr. Robert Lazor (601-634-2935, Bob.L.Lazor@erdc. usace.army.mil). This technical note should be cited as follows:

Lichvar, R., Gustina, G., and Bolus, R. (2002). "Duration and frequency of ponded water on arid Southwestern playas," WRAP Technical Notes Collection (ERDC TNWRAP-02-02), U.S. Army Engineer Research and Development Center, Vicksburg, MS. www.wes.army. mil/el/wrap

NOTE: The contents of this technical note are not to be used for advertising, publication, or promotional purposes. Citation of trade names does not constitute an official endorsement or approval of the use of such products. 